\title{
STEREOTYPES AND PREJUDICES IN THE LEGAL REPRESENTATION OF VIOLENCE AGAINST WOMEN. A SOCIO-CULTURAL ANALYSIS OF THE JUDGMENTS IN THE ITALIAN COURTS
}

\begin{abstract}
Annotation. The paper presents and discusses data from the research «STEP - Stereotype and Prejudice. For a Cultural Change in Gender Representation in the Judiciary, Law Enforcement and Media Reporting». The research is coordinated by Professor Flaminia Saccà, and financed by the Italian Presidency of the Council of Ministers - Department for Equal Opportunities. The analysis conducted on a sample of 283 judgments relating to crimes of violence against women (domestic violence; sexual violence; murder / femicide; human trafficking; stalking) shows how stereotypes and prejudices regarding gender relations, role expectations and women representation are still strongly rooted in our society and, at least partially, in our courtrooms. The paper identifies and describes the main critical elements found in the representation of violence against women proposed by the judgments' language: the representation of the victim (and the key role of her testimony); the presence of three recurrent biases (family dispute bias, jealousy bias and raptus bias); the almost total lack of references to the main international regulatory sources (CEDAW and the Istanbul Convention).
\end{abstract}

Keywords: gender violence, gender bias, legal language.

For citation: Sacca F., Massidda L. (2021) Stereotypes and prejudices in the legal representation of violence against women. A socio-cultural analysis of the judgments in the Italian courts. Science. Culture. Society. Vol. 27. № 2. P. 62-73. DOI: 10.19181/nko.2021.27.2.6

1. Introduction. The paper presents data from the «STEP - Stereotype and Prejudice. For a Cultural Change in Gender Representation in the Judiciary, Law Enforcement and Media Reporting» research. The research has been coordinated by Professor Flaminia Saccà and financed by the Italian Presidency of the Council of Ministers Department for Equal Opportunities. The research considered 5 types of violence against women - domestic violence; sexual violence; murder/femicide; human trafficking; stalking - in the context of two linguistic domains: legal language, with the analysis of 283 sentences issued by Italian criminal courts and the language of the media, through the analysis of over sixteen thousand articles published between 2017 and 2019 in the main national and local newspapers [1]. The project was carried out in partnership with "Differenza Donna ONG", one of the leading associations in Italy for the prevention and contrast of gender-based violence and for the support of women victims of violence ${ }^{1}$. The University of Tuscia, as project leader, was responsible for the research activities, while the partner Differenza Donna coordinated the planned training activities ${ }^{2}$.

In this article, we will focus our attention on the analysis of legal language. The analysis is based on a corpus of judgments consisting of four different collections. Three of these were included in the analysis through the reports of professionals, two judges and a lawyer, with a long experience in the legal treatment of violence against

1 For more information: https://www.differenzadonna.org/en/

2 For an overall in-depth analysis of the STEP research project and its various activities, please refer to the website www.progettostep.it. 
women, and members of the scientific council of the project. To these three qualitative repertoires, it is added a fourth database of judgments built directly by the UNITUS research team through access to the Juris Data-De Jure and Cedam Utet Ipsoa digital archives. The analysis was conducted through human content analysis methodology.

Before going into the details of the judgment's analysis, let's take a look at the Italian scenario, with some background data on the phenomenon of gender-based violence in our country. As Figure 1 shows, according to the 2019 agency data provided by the Ministry of the Interior and elaborated by our research group, the most frequent crime, over $50 \%$ of cases, is attributable to domestic violence. The data confirm how the threat to women's safety in our country comes above all from their own family sphere, from their most intimate and private relationships. Sample data collected in 2018 by the Italian National Institute of Statistics (ISTAT), during the «Stereotypes about Gender Roles and the Social Image of Sexual Violence» investigation, have shown that almost one in three Italian women have been victims of physical or sexual violence $(31,5 \%, 6.8 \text { million })^{3}$. Such a worrying expansion of the phenomenon is accompanied by the alarming spread in the Italian society of gender biases and stereotypes in the representation of male violence against women: according to ISTAT survey data, $39.3 \%$ of respondents consider it correct to argue that «women who do not want to have sexual intercourse are able to avoid it», $23.9 \%$ share the idea that woman's dress and look can cause sexual harassment, $15.1 \%$ consider the woman who uses alcohol or drugs at least partly responsible for what happened to her, $10.3 \%$ of respondents think accusations of sexual assault are often false ${ }^{4}$.

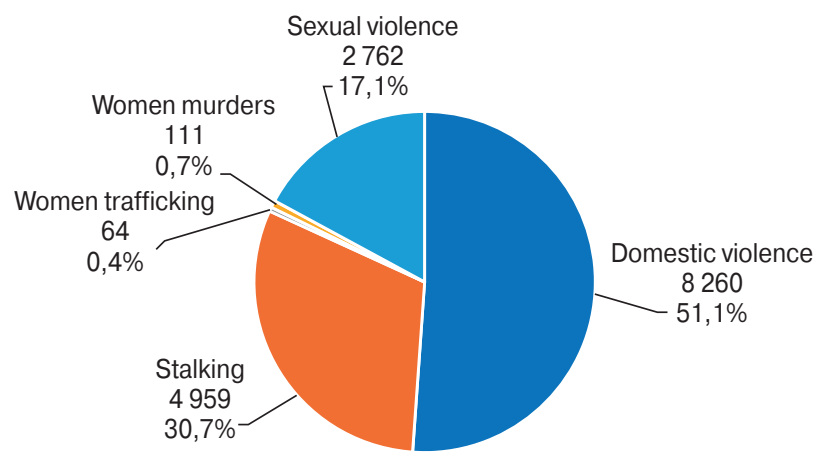

Figure 1: Data on violence against women in Italy: Agency Data (2019)

Source: University of Tuscia on data from Italian Ministry of the Interior

In this social scenario, one of the STEP Project research lines examined the representation of violence against women offered by the legal language. Through the analysis of judgments, we have identified in particular three main themes: 1) the representation of the victim (and the key role of her testimony); 2) the presence of three recurrent biases (family disputes bias, jealousy bias and raptus bias); 3) the almost total lack of references to the main international regulatory sources: the CEDAW and the Istanbul Convention.

3 Report: Stereotypes about gender roles and the social image of sexual violence // ISTAT. URL: https://u. to/zE5QGw (last request 12.03.2021).

4 Stereotypes about gender roles and the social image of sexual violence in Italy // ISTAT. URL: https://u. to/FlBQGw (last request 12.03.2021). 
2. Victim's testimony. In cases of violence against women, the Italian law recognizes a particular centrality to the victim's testimony. As certified on more than one occasion by the Supreme Court of Cassation, it might constitute, on its own, the basis of a verdict ${ }^{5}$. This is a determining legal principle for the types of crimes, as we have seen through agency's official data (courts, police agencies, hospitals, and shelters), which very often occur in private spaces, behind closed doors ${ }^{6}$. A violence, therefore, that is systematically removed from the public gaze and that often has no other witness than the victim herself. This private dimension that characterizes violence against women, especially in its most common expression (intimate partner violence), its structural placement in an intimate space, hidden to the gaze of the others, makes domestic violence a different type of crime, a crime with its specific narrative, «a crime that "needs" a story» [2, p. 289]. This juridical «protagonism» of the victim must be managed with great attention. Otherwise, the risk is that the victim will actually be the one to undergo the trial, not the accused. With the judgment shifting from man's actions to women's behaviour or her character [3, p. 227]. This reversal of narrative roles in the trial [4, p. 134] can easily open a door to secondary victimization. According to the ethnographic analysis conducted by Alessandra Gribaldo in the Italian courts, this is recurrent in cases of intimate partner violence, when «the subjectivity of the injured party (rather than that of the accused) takes center stage in the trial» [5, p. 749], «the question "who did what to whom and with what intentions?" often rapidly slides into a question that the woman is requested to answer: "Who are you?"» [5, p. 749] and «the confession mechanism was paradoxically applied to the victim instead of the perpetrator» ${ }^{7}$.

2.1 Supporting victims' credibility. This legal principle that recognizes a decisive importance to the victim statements results in a very specific linguistic habitus, with a systematic use in convictions of crimes related to gender-based violence of an edifying adjectivisation in the qualification of the victim's testimony. In particular, it is possible to identify some recurring semantic domains in the words used by the judges to describe - and attempt to "secure" - the victim's testimony (fig. 2).

Most of the adjectives identified directly enhance the victim's story. They have to do with the appreciation of the testimony from the point of view of its accuracy. The victim's report is then described as punctual, precise, complete, detailed, circumstantial, analytical, meticulous, accurate, extensive, thorough, checked, and specific. The aim of the accuracy domain is to enhance the objective quality of the victim's testimony, so that it can effectively perform, even on its own, its legal function as the basis of the claim of criminal liability of the accused. The second domain present in the judgments is that of credibility. This is not just about enhancing the objective quality of the victim's story. Describing the testimony of the aggrieved party as trusted, credible, noncontradictory, congruent, plausible, consistent, free of aporie, convincing, truthful,

\footnotetext{
5 «declarations of the injured person can alone, without the need for extrinsic evidence, be placed as a basis for the assertion of criminal responsibility of the accused, after verification, accompanied by suitable reasons, of the declarant's subjective credibility and the intrinsic reliability of her narrative» (Cass., Sez. III, October 12th, 2018).

6 The most serious form of violence against women, feminicide, clearly returns the predominantly intimate, private, family dimension that characterizes gender-based violence: in 2019 only $11.7 \%$ the murderer was unknown to the victim (or unidentified), while in $61.3 \%$ of cases he was a partner or former partner, in $22.5 \%$ another relative and in $4.5 \%$ still an acquaintance (ISTAT, 2019).

7 «The testifying victim is, instead, called on to make a confession about herself in relation to her husband (institutional figure), her lover (relational figure), or her aggressor (a figure that must be assembled-discoveredjudged» [5, p. 749].
} 

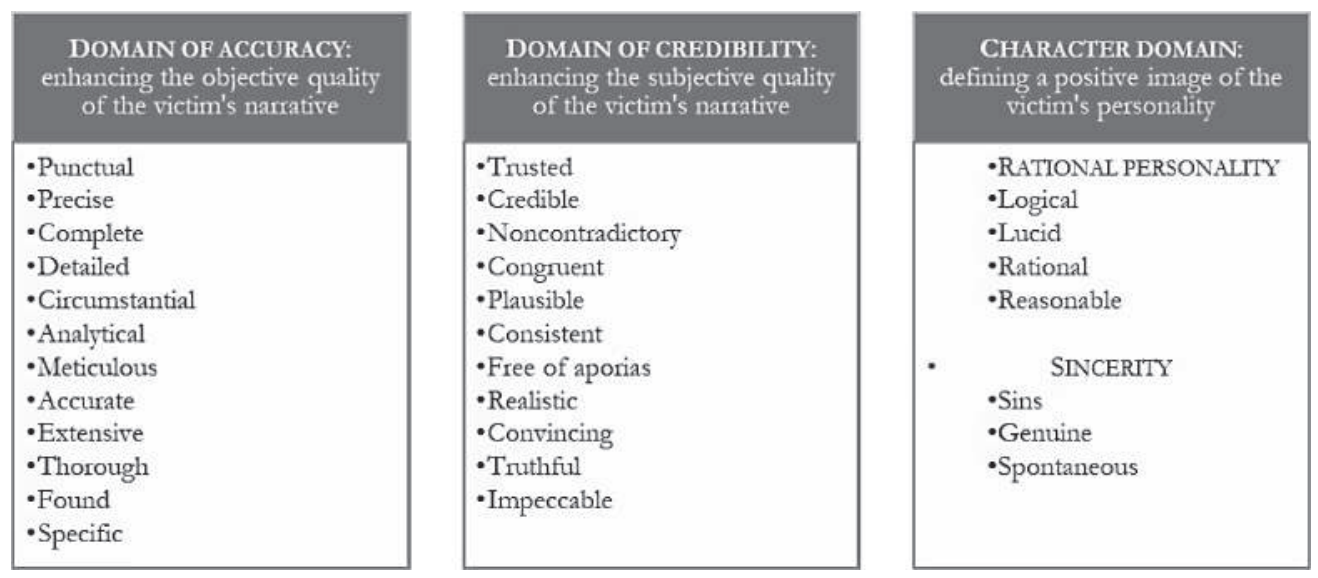

Figure 2: Recurrent edifying adjectivisation in the victim's testimony

Source: STEP - Stereotype and Prejudice. For a Cultural Change in Gender Representation in the Judiciary, Law Enforcement and Media Reporting

impeccable, the judges are already building the semantic structure of support for their final assessment. The positive enhancement thus begins to extend from the object (testimony) to the subject who made it (the victim). The third and final domain is that of "personality". In this case, the adjectives chosen to qualify the statements made by the aggrieved party serve mainly to construct a positive image of the victim's character. Here we have two subdomains that emerge, that of the "rational personality" (rational, reasonable, logical, lucid) and that of "sincerity" (spontaneous, sin, genuine). This linguistic habit is certainly attributable to the legal principle that we have recalled, but it can also be read as an attempt, implemented with a greater or lesser degree of awareness by the judge, to react to the gender bias that labels the woman's words, in principle, as less credible [6]. The edifying adjectivisation works as a "semantic counterbalance" that the language of the judgment feels compelled to produce when it is advocating, in the field of the attribution of credibility, a «flipping of gendered hierarchies» [3, p. 185].

2.2 Credibility markers. To better support the solidity of the victim's narrative, judgments resort, in several cases, to further «credibility markers» that enhance the testimony of the aggrieved party but partly reproduce a stereotypical representation of women and gender relations (Fig. 3).

Some «credibility markers» do not seem particularly problematic, such as the «emotionality marker» or the «fragility marker». It is important, however, when the judge uses them, that these attributes are not stereotyped with an alleged «nature» of the female character. It's crucial to explicitly identify the causal link between the victim's emotional status, her fragility or vulnerability, and the specific power relationship in which the man acted violently. Two other recurring "credibility markers" are those of forgiveness and modesty. These two semantic constructs are more problematic because they risk to reproduce and legitimize a stereotyped binary representation of the feminine that identifies women according to the Manichaean logic typical of the Madonna/whore dichotomy [7]. This frame risks to imply that the woman is credible if she is modest, if she is able to forgive, if she is willing to sacrifice herself for love or family. Applying this logic, the risk is that the uninhibited, legitimately resentful, or simply agentic woman is unfairly considered, at least in her role as a victim, to be less 


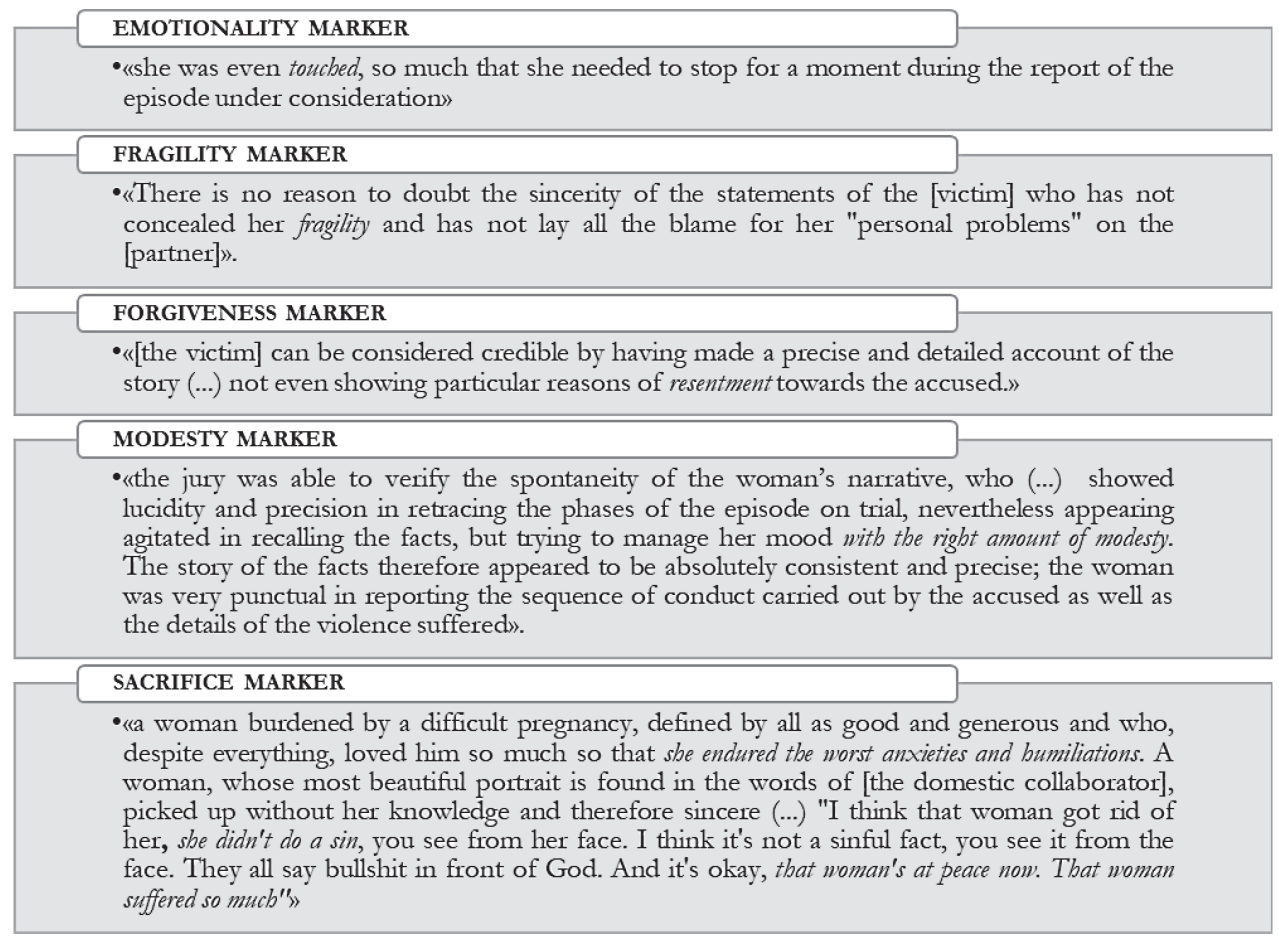

\section{Figure 3: Credibility markers}

Source: STEP - Stereotype and Prejudice. For a Cultural Change in Gender Representation in the Judiciary, Law Enforcement and Media Reporting

credible. Representing the victim within a socially shared stereotype can implicitly act as a marker of the credibility of her testimony. In any narrative, it is easier for us to consider a credible character, one that matches our socially coded role expectations. The problem is that in the case of women who report male violence, these expectations tend to be built on gender stereotypes and prejudices [8]. The credibility of the woman is thus measured on her degree of «conformity with traditional gender norms, particularly those governing sexual behaviour» [8, p. 53; 9]. The use of "credibility markers" creates a paradox that can be seen in terms of cultural conflict. The judge, in an attempt to protect the victim of violence, reproduces precisely that stereotypical and binary representations of the woman that, socializing to an incorrect culture of gender relations, support the viral spread of violence against women.

3. Recurrent Gender Bias. While "credibility markers" require the judge to be careful and to avoid reproducing and legitimizing gender stereotypes in building their argumentative structure of support for the victim's testimony, the three social biases that our research has found to be recurrent in the texts of judgments immediately determine a criticality in the legal language representation of violence against women. The problem is not how these three social biases are used, but their simple - and recurring - presence. This immediately affects the interpretation - and judgment of gender-based violence, imposing a distorted perspective on the phenomenon. To begin with, let us consider the bias of family disputes.

3.1 Family disputes bias. When violence against women occurs within a relationship of proximity, the adjectives that recur in the description of the sentimental relationship systematically recall the frame of litigation (Fig. 4). 


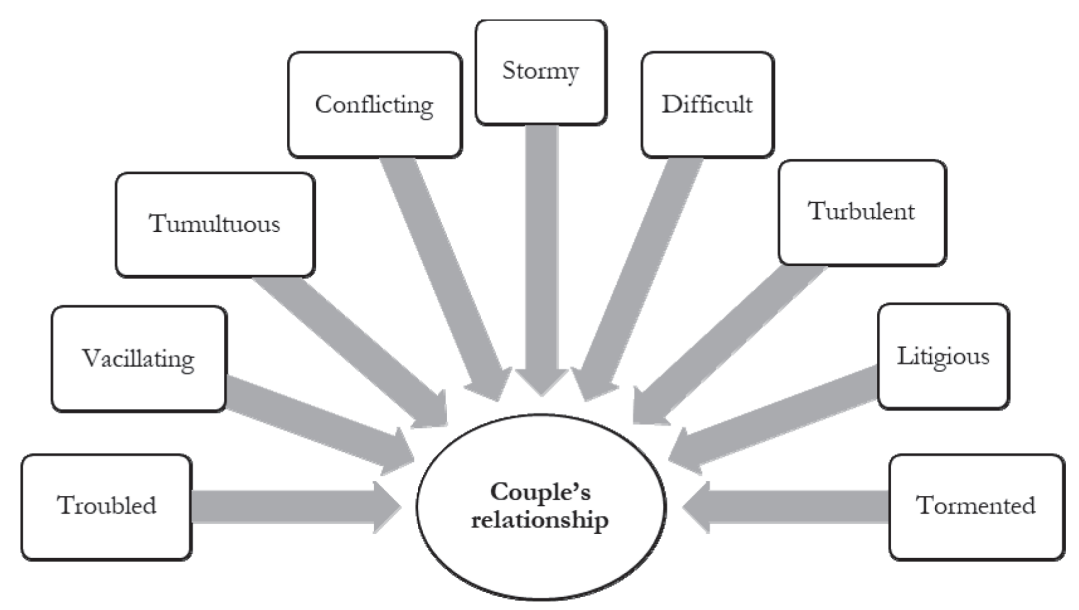

Figure 4. Recurrent adjectives in the description of the couple's relationship

Source: STEP - Stereotype and Prejudice. For a Cultural Change in Gender Representation in the Judiciary, Law Enforcement and Media Reporting

The problem is that this bias can act as a factor of trivialization of the violent behaviours of which women are victims ("these things happen"). And it can also lead to an incorrect attribution of responsibility, tracing the violence back to couple's dynamics rather than to the action of the aggressor. Family disputes' frame determines its maximum distortion potential when the woman is indicated as the main responsible for the conflictual relationship. In this way, the mechanism of secondary victimization is fully activated.

It is the society that systematically brings this bias into the courtroom. The same goes for the defendant, who has every interest in proposing this «exonerating narrative» [3, p. 178]: «he admitted frequent and violent disputes within the affective relationship and cohabitation with the offended person, diminishing the severity of the same, almost bringing them back to a normal internal confrontation within the couple» ${ }^{8}$. However, the bias of family disputes is so well established in our culture that it is often used to frame violence not only by its perpetrators, but also by its victims ${ }^{9}$ : «You ask me if I usually quarrel with my partner and I reply that it happens that we quarrel but the quarrels stem from the fact that he wants to give me good advice» ${ }^{10}$. In this semantic context it becomes decisive the judges' ability to escape, in their assessment, the easy temptation to reproduce and legitimize a bias that is so deeply rooted in society, and that often finds its first legal formalization in the defense thesis supported by the defendant's lawyer ${ }^{11}$. When this does not happen, as in this case,

\footnotetext{
8 Court of Palermo, domestic violence, 2019.

${ }^{9}$ When the victim, in the interpretation of her couple relationship, adopts schemes imposed by the violent partner, she demonstrates the strength of masculine domination, its ability to impose recognition and submission. According to Bourdieu, it is in this compulsion of the point of view that symbolic violence is imposed, when the relationship of power is introjected by the dominated subject so deep that she cannot even imagine that she could think the world and her position in it outside and beyond that dominant schemes of perception [10, pp. 13-14].

${ }^{10}$ Court of Palermo, domestic violence, 2019.

11 «One element that always emerges in courtroom questioning and discussions is the normalization of violence through the trivialization of domestic conflict: The defense tends to use a simplifying, gender-blind language. For instance, the defense systematically replaces terms such as violence or even conflict with terms like squabble, scuffle, or predicament and frequently uses impersonal expressions and the passive voice to describe episodes of violence ("some slapping occurred") in an overall tendency to trivialize the violent event, on one side, and, on the other side, to deny that the acts were perpetrated by the accused» [5, p. 745].
} 
the judgment clearly slips into a bad practice: «[man's violence] also appears to be caused by a strong incompatibility of temperament with the aggrieved party that ended up triggering the violent disposition of the [defendant]» ${ }^{12}$. In this verdict, the frame of family disputes not only favors the process of normalization of violence, but also activates a mechanism of victim blaming: not only it is the strong incompatibility of temperament that has caused violent behaviour, but it is evidently the woman who brings the greatest responsibility for the climate of quarrelsomeness that animates the couple's relationship and it's she who triggered the violent disposition of the partner. This complicity between the language of society and the language of the legal system is also favoured by the habits of law enforcement, the first institutions that normally intervene in the context of the crime and therefore have a strong power, with their vocabulary, to orient its representation. From this point of view, their practice to adopt the disputes' frame in reporting their interventions in cases of domestic violence is very problematic [11-12].

3.2 Jealousy bias. The second bias, that of jealousy, is also systematically brought into the courtroom by civil society. Although it no longer represents a legal issue, «the statute permitting honor killing in Italy was abolished in 1981, the theme of jealousy remains relevant in abuse trials» [5, p. 745], still establishing itself in a recurring way as an ethical issue capable of conditioning the representation of violence against women and its legal narratives. Once again, the ability of the judge not to grant some legal legitimacy to this interpretation of gender violence is decisive. We can take as an example a judgment of the Court of Civitavecchia (2017). The frame of jealousy, introduced by a witness («the witness confirms that the accused was obsessed with jealousy») and confirmed by the victim herself (who explains how the initial «jealousy had turned into a real claim of possession»), is also recalled in the conclusion of the judge («the crime can be supplemented by the continuous and invasive control by the husband, devoured by a pathological and irrepressible jealousy towards his wife»). The witness describes the defendant as obsessed with jealousy. The victim emphasizes the intensity of this feeling, speaking of an initial jealousy that over time becomes a real claim to possession and finally, the main problem, the judge confirms this pattern by speaking in his conclusions of pathological and irrepressible jealousy. Here the adjectives chosen by the judge are decisive again: the jealousy that consumes the husband is irrepressible and pathological. Both attributes amplify the potential for deaccountability of violence already present in the incorrect use of the jealousy frame: the first suggesting the idea of an impulse that is not controllable by the subject; the second by inappropriately recalling a medical horizon of meaning ("pathological") for an absolutely socio-cultural condition. If the violent man is described as a "sick man" who has "lost control" due to jealousy, it is evident that a semantic mechanism is in place justifying his actions. From a linguistic analysis perspective, thinking about the bias of jealousy, it is important, as the aforementioned case has suggested to us, to observe in detail the adjectives that are used in the judgments to "discredit" this feeling. We can bring them back to four frames: dramatizing effect, control loss, disease, and injustice (fig. 5).

Of these frames, only the first, in which the chosen lexicon simply aims to dramatize the intensity of the mood (jealousy is described as strong, pressing, fierce), does not add significant additional elements of criticality to the use of the jealousy bias. While both the frame of control loss (unstoppable, overwhelming, irrepressible, blinding, unrestrained, furious) and the frame of disease (pathological, morbid, obsessive, delirious,

${ }^{12}$ Court of Salerno, domestic violence, 2018. 


\begin{tabular}{|c|c|c|c|}
\hline Dramatizing EFFECT & CONTROL LOSS FRAME & FrameS OF THE DISEASE & FrameS OF «INJUSTICE» \\
\hline Enhances mood intensity & \multicolumn{2}{|c|}{ Risks de-responsibility effect } & $\begin{array}{c}\text { Legitimizes the bias and } \\
\text { stereotypes that support it }\end{array}$ \\
\hline Strong & Unstoppable & Pathological & Unjustified \\
Pressing & Overwhelming & Morbid & Unwarranted \\
Fierce & Irrepressible & Obsessive & \\
& Blinding & Delirious & \\
& Unrestrained & Paranoid & \\
& Furious & Paroxysmal & \\
\hline
\end{tabular}

Figure 5. The adjectives of jealousy

Source: STEP - Stereotype and Prejudice. For a Cultural Change in Gender Representation in the Judiciary, Law Enforcement and Media Reporting

paranoid, paroxysmal) risk producing a deresponsible effect towards violent behavior. The most harmful frame, however, could be the fourth, that of "injustice". Here, the feeling of jealousy is characterized through the choice of adjectives that insist on its being "unfair" (jealousy is in this case unjustified or unwarranted), because it emerged without the behavior of the offended woman having determined it in reality. The danger here is that a negative adjective will have a superficial effect of stigmatization of the emotional state, while in its substance it deeply operates as a legitimization of the stereotypes and prejudices that support it. The condemnation of "unjustified" jealousy risks implying the acceptability of that feeling, where it derives from a legitimate suspicion or is even confirmed by verified facts.

3.3 The bias of raptus. The third and final bias is that of raptus. The term raptus is rarely found in judgments (in our database we find 3 occurrences relating to 2 sentences). And even the press seems to have substantially excluded it from the vocabulary used in the narration of violence against women (277 occurrences in 220 articles, $1.32 \%)$. Although the term "raptus" has been practically banned, the frame of an almost uncontrollable impulse to which the perpetrator of violence against women

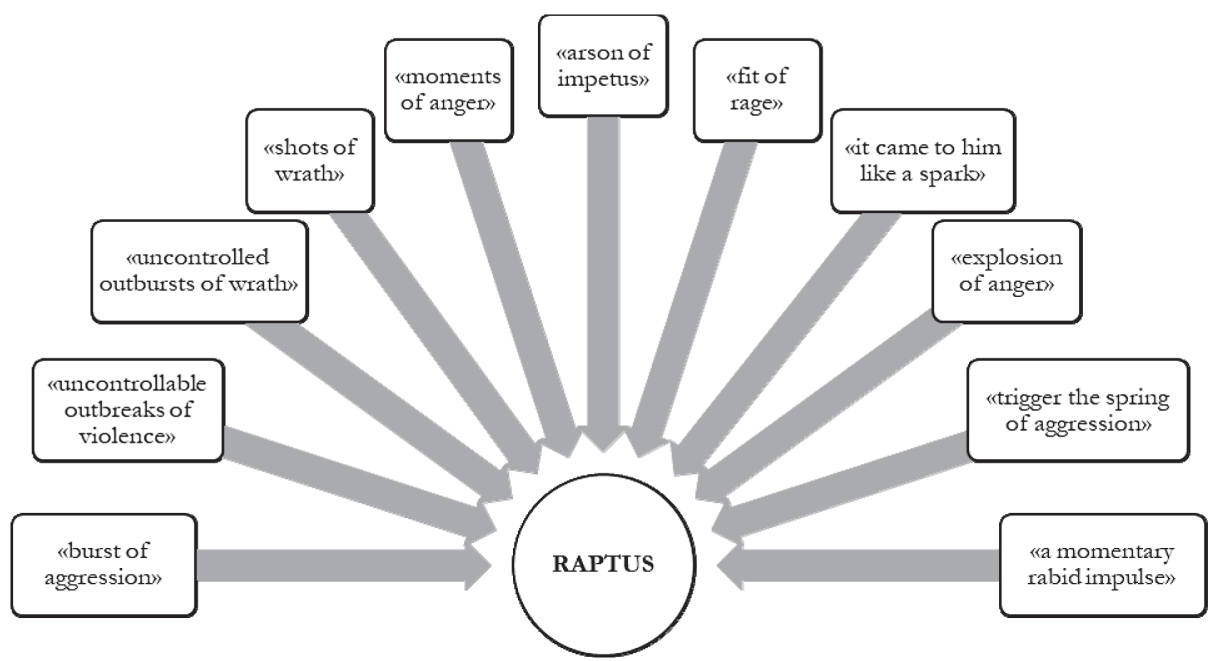

Figure 6. Raptus semantic surrogates

Source: STEP - Stereotype and Prejudice. For a Cultural Change in Gender Representation in the Judiciary, Law Enforcement and Media Reporting 
responds in an instinctual way persists in the judgments, finding hospitality in less strong, but perhaps more insidious semantic constructs: «an explosion of anger», «an impetus of wrath», «an uncontrollable outbreaks of violence», are expressions that can perform the same de-responsible function of the term raptus.

This judgment of the Court of Genoa (2018), relating to a crime of feminicide, is a paradigmatic example of how the bias of raptus, under false pretences, can still condition the prosecution: «The two are in the house, arguing, drinking and still arguing and, in a fit of rage, the defendant grabs a large knife in the kitchen and hits [the victim] with a single slit that pierces the lung and determines her death in a few minutes». Discussion, alcohol, discussion, anger, stabbing, death. Here we can see how the two biases that we have identified, that of quarrelsomeness and that of raptus, overlap and support each other in narratively building a causal chain of the event that takes responsibility away from the killer. Continuing his argument, the judge questions the prosecutor about the reconstruction offered by the latter. In his request he would have overlooked «the much more significant appreciation that deserves the context in which the murder occurs and the obvious fraud of impetus (dolo d'impeto) that has pushed the murderous action». Here the use of the raptus frame, translated into the legal lexical technicality of the «dolo d'impeto», as a semantic mechanism that disempowers the violent action becomes paradigmatic: it is this exceptional emotional state that pushes the murderous action. We can almost see the "dolo d'impeto" grabbing the knife and sticking it into the victim's body. Taking it out of the hands of her abusive husband. The worst, however, has yet to come. The sentence continues: «It should also be pointed out that while it is indisputable that in the past [the defendant] has been responsible for violent behaviour, on other occasions, the accused, although legitimately resentful of his wife's behaviour, has shown that he wants to dominate his own shot of anger, managing to force himself to prevent from doing some madness». Not only is the behaviour of the feminicide due to a moment of loss of control, but it is clearly the victim who is responsible for it. At this point, the judge is ready to make the process of re-victimization explicit and directly shifts the responsibility of the case to the woman killed:

The wife (...) is not determined in her choices, manifests love and immediately after contempt and this drives her husband 'crazy'. It is also credible that the [victim] completely drunk, contradictory, and inconsistent as always (...) has provoked [the defendant] by questioning his determination and ability to prove himself as a 'man' and severely testing his self-control. The scene has no witnesses, but it is indisputable that the tone of the discussion has been very heated and that the woman, completely drunk may have said or done anything (...). Certainly, the impulse that led [the defendant] to hit his wife with the knife came from a very strong and sudden feeling, he did not simply act under the pressure of jealousy but from a mixture of anger and despair, deep disappointment and resentment (...) [He] acted under the pressure of a very intense mood, not pretentious, nor humanly completely incomprehensible.

The wife «drives her husband crazy». The bad wife, «contradictory and inconsistent as always», provoked him. She questions his masculinity, his «ability to prove himself as a 'man'». The woman is «completely drunk». The court's repertoire of justifications is almost embarrassing. The final nail is paradigmatic of the spirit with which the judgment was written. Yes, he killed her with a stab. She was his wife, but a drunken and adulterous wife. Therefore, his mood was very intense, not pretentious, nor humanly completely incomprehensible. In this judgment we have a perfect example of what Kate Manne called himpathy, «the flow of sympathy away from female victims toward their male victimizers» [3, p. 23]. A flow that uses the misogynistic mechanism of the victim blaming and that relies on the construction of an unfair comparison between «an innocent and a less innocent victim» [13, p. 180]. The condemnation shifts from man's to woman's behavior, exploiting once again stereotypes and prejudices deeply inscribed into the Madonna/whore dichotomy. 
4. Conclusions. CEDAW \& Istanbul Convention, two notable absences. One last element of analysis. In the two areas of public language that we have taken into account with the STEP Project, the language of judgments and the language of newspapers, the two main international regulatory sources - the Convention on the Elimination of all Forms of Discrimination Against Women (CEDAW) and the Council of Europe Convention on preventing and combating violence against women and domestic violence (Istanbul Convention) - are essentially absent, not represented. In the database related to the 2017-2019 press review (16,715 cases) the Istanbul Convention is mentioned 93 times in 84 articles, while CEDAW is appointed in only 3 cases. In the UNITUS database (184 cases), we find only six judgments which in their text refer directly to the Istanbul Convention, and not any reference to the behavior of the CEDAW. These absences reveal the habit, shared by the judiciary and the press, of using an episodic frame when observing - and representing - violence against women. This perspective crushed on the single "case" fails to recognize those structural conditions of violence against women that the Istanbul Convention immediately reveals in its preamble:

- «Recognising that violence against women is a manifestation of historically unequal power relations between women and men, which have led to domination over, and discrimination against, women by men and to the prevention of the full advancement of women» ${ }^{13}$;

- «Recognising the structural nature of violence against women as gender-based violence, and that violence against women is one of the crucial social mechanisms by which women are forced into a subordinate position compared with men» ${ }^{14}$.

The most critical element in this propensity of judgments to use the «framework of incidentalism» [14] lies in the fact that the judge, adopting this narrow perspective on the case under discussion, means that his point of view is paradoxically closer to that of the abuser man rather than that of the most advanced international legislation in the prevention and contrast to violence against women. Violent men resort to the paradigm of incidentalism in order «to excuse, minimise, disavow and detach themselves from their harmful behaviour» [15, p. 115], «to disconnect the 'incident' from the context in which it took place» [15, p. 118]. On the other hand, the Convention's point of view, with its holistic view, is very close to that of women who are victims of gender-based violence ${ }^{15}$. When the law adopts the talk of abusive men it is not just minimizing violence, it is actually disconnecting it from «gender, power and control» [15, p. 124]. It is hiding the structural gender-based nature of violence against women.

Author Contributions: The essay is the result of a collaborative work of the two authors, who equally contributed to it (50\%). According to the CRediT standard (https://casrai.org/credit/) the scientific roles played by the two authors are so distributed: Conceptualization, F.S., L.M.; Data Curation, F.S., L.M.; Formal Analysis, F.S., L.M.; Funding Acquisition, F.S.; Methodology, F.S., L.M.; Project Administration, F.S.; Supervision, F.S.; Writing - Original Draft, L.M.; Writing - Review \& Editing, F.S.

${ }^{13}$ Council of Europe Convention on preventing and combating violence against women and domestic violence, «Istanbul Convention», 2011.

${ }^{14}$ Ibid.

$15 \ll$ What women describe is an ongoing, 'everyday' reality in which much of their behaviour is 'micromanaged' by their abuser: this includes what they wear, where they go and who they see, household management and childcare» (15, p. 114). 


\section{References / Библиографический список:}

1. Saccà, F. (ed.) (2021). Stereotipo e pregiudizio. La rappresentazione giuridica e mediatica delle violenza di genere. Franco Angeli, Rome-Milan.

2. Gribaldo, A. (2019) The Burden of Intimate Partner Violence: Evidence, Experience, and Persuasion. PoLAR: Political and Legal Anthropology Review. 42(2), pp. 283-297. https:// doi.org/10.1111/plar.12309.

3. Manne, K. (2017) Down girl: The logic of misogyny. Oxford University Press, Oxford.

4. Di Nicola, P. (2018) La mia parola contro la sua: Ovvero quando il pregiudizio è più importante del giudizio. HarperCollins, Milan.

5. Gribaldo, A. (2014) The paradoxical victim: Intimate violence narratives on trial in Italy. American Ethnologist. 41(4), pp. 743-756. https://doi.org/10.1111/amet.12109.

6. Marsh, G. (2011) Trust, testimony, and prejudice in the credibility economy. Hypatia. 26(2), pp. 280-293. https://doi.org/10.1111/j.1527-2001.2010.01152.x.

7. Macdonald, M. (1995) Representing women. Myths of femininity in the popular media. Edward Arnold, London.

8. Easteal, P. L. (2002) Looking through the prevailing kaleidoscope: Women victims of violence and intersectionality. Sister in Law, A Feminist Law Review. 6, pp. 48-77

9. Saccà, F. (2003) La società sessuale. Il controllo sociale della sessualità nelle organizzazioni umane. FrancoAngeli, Rome-Milan.

10. Bourdieu, P. (2001) Masculine domination. Stanford University Press, Stanford.

11. Edwards, S. (1989) Policing 'Domestic' Violence: Women, the Law and the State. Sage, London.

12. Lea, S. J. \& Lynn, N. (2012) Dialogic reverberations: police, domestic abuse, and the discontinuance of cases. Journal of interpersonal violence. 27(15), pp. 3091-3114. https://doi. org $/ 10.1177 / 0886260512441075$.

13. Burman, M. (2010) The ability of criminal law to produce gender equality: Judicial discourses in the Swedish criminal legal system. Violence Against Women. 16(2), pp. 173-188.

14. Hearn, J. (1998) The Violences of Men. Sage, London.

15. Kelly, L. \& Westmorland, N. (2016) Naming and defining 'domestic violence': Lessons from research with violent men. Feminist review. 112(1), pp. 113-127.

The article was submitted on April 28, 2021. Accepted on May 24, 2021.

\section{Information about the authors}

Flaminia Saccà, Full Professor of Political Sociology,

Tuscia University. Viterbo, Italy.

e-mail:sacca@unitus.it

ORCID: 0000-0001-5960-9169

Luca Massidda, Researcher in Political Communication Studies,

Tuscia University. Viterbo, Italy.

e-mail: luca.massidda@unitus.it

ORCID: 0000-0003-2372-3036

Scopus Author ID: 57210830485 
Ф. Сакка ${ }^{1}$ Л. Массидда ${ }^{1}$

${ }^{1}$ Университет Тушии. Витербо, Италия

\title{
СТЕРЕОТИПЫ И ПРЕДРАССУДКИ В ПРАВОВОМ ПРЕДСТАВЛЕНИИ ГЕНДЕРНОГО НАСИЛИЯ. СОЦИОКУЛЬТУРНЫЙ АНАЛИЗ СУДЕБНОЙ ПРАКТИКИ ИТАЛИИ
}

\begin{abstract}
Аннотация. В статье рассмотрены результаты исследовательского проекта «STEP - Stereotype and Prejudice. For a Cultural Change in Gender Representation in the Judiciary, Law Enforcement and Media Reporting» [Стереотипы и предубеждения. На пути к культурным изменениям гендерных представлений в рамках судебной системы, правоохранительных органов и СМИ]. Исследование координируется проф. Ф. Сакка при финансовой поддержке Президиума Совета министров Италии - Департамента по равным возможностям. Анализ, проведенный на выборке из 283 судебных решений, касающихся преступлений, связанных с насилием в отношении женщин (бытовое насилие; сексуальное насилие; убийство / фемицид; торговля людьми; преследование), показывает, насколько сильно укоренились ролевые стереотипы и гендерные предрассудки в отношении женщин в нашем обществе и, в определённой степени, в залах суда. В работе выделены ключевые элементы, присутствующие при рассмотрении дел о насилии в отношении женщин, изложенные в терминологии судебных решений. Среди них: образ жертвы (и ключевая роль ее показаний); наличие трех повторяющихся предубеждений (предвзятость в отношении семейных споров, предвзятость в отношении ревности и предвзятость в отношении принуждения); почти полное отсутствие ссылок на основные международные нормативные источники (CEDAW и Стамбульская конвенция).
\end{abstract}

Ключевые слова: гендерное насилие, гендерная предвзятость, юридический язык.

Для цитирования: Сакка Ф., Массидда Л. Стереотипы и предрассудки в правовом представлении гендерного насилия. Социокультурный анализ судебной практики Италии // Наука. Культура. Общество. 2021. Том 27, № 2. C. 62-73. DOI: 10.19181/nko.2021.27.2.6

Дата поступления в редакцию: 28.04.2021.

Принята к печати: 24.05.2021.

\section{Сведения об авторах: \\ Фламиния Сакка, доктор политических наук, профессор, Университет Тушии. Витербо, Италия. e-mail: $\underline{\text { sacca@unitus.it }}$}

Лука Массидда, научный сотрудник, исследование политических коммуникаций, Университет Тушии. Витербо, Италия. e-mail: luca.massidda@unitus.it 